\title{
Neural Networks Assessment of Beam-to-Column Joints
}

\section{P. C. G. da S. Vellasco}

S. A. L. de Andrade

and J. G. S. da Silva

Universidade do Estado do Rio de Janeiro

Faculdade de Engenharia

Rua São Francisco Xavier, 524, sala 5016A

20550-900 Rio de Janeiro, RJ. Brazil luciano@eng.uerj.br vellasco@eng.uerj.br

andrade@civ.puc-rio.br and jgss@eng.uerj.br

M. M. B. R. Vellasco

Pontifícia Universidade Católica do Rio de Janeiro Departamento de Engenharia Elétrica Rua Marquês de São Vicente, 225. 22453-900 Rio de Janeiro RJ. Brazil marley@ele.puc.rio.br
This paper proposes the use of artificial neural networks to predict the flexural resistance and initial stiffness of beam-to-column steel joints using the back propagation supervised learning algorithm. Three types of steel beam-to-column joints were investigated: welded, endplate and bolted with top, seat and double web angles, respectively. The neural networks results proved to be consistent with experimental and design code reference values.

Keywords: structural engineering, semi-rigid joints, steel structures, neural networks, semi-rigid behaviour, flexural resistance and joint stiffness

\section{Introduction}

Structural joints play a fundamental role in the steel structures global response. The real behaviour of a structural joint has been investigated through several experimental tests such as: Faella et al. (1999), Aggarwal (1994), Weynand and Sahl (1984), Zoetemeijer and Munter (1983), Simek and Wald (1991), Hummer and Tschemmernegg (), Cruz et al. (1998), Janss et al. (1987), Goverdan (1983), Nethercot et al. (1995), Bjorhovde et al. (1990), Chen et al. (1993), Kishi et al. (1987), Lima et al. (2002), Simões et al. (2001), Azizinamini et al. (1987), Azizinamini et al. (1989). The main objective of these tests was to determine the physical and geometric parameters that influence the joints structural behaviour.

From these test data, the joints can be classified according to their bending moment and associated rotation capacity. Generally, the joints are classified as rigid or flexible. However, this hypothesis is not accurate, since most of the steel structural joints do not match any of these two extremes. Despite this fact, the traditional nonsway frame design usually adopts flexible joints. Unfortunately, when sway frame design is required, rigid stiffened joints have to be used. On the other hand, rigid joints have higher fabrication costs and give rise to a number of questions about their real structural behaviour. To overcome these difficulties, the semi-rigid joints fit as a natural solution, reducing the final cost and presenting a more realistic structural behaviour.

Few investigations using artificial neural networks to predict joints behaviour were found in literature. Abdalla and Stavroulakis (1994) and Stavroulakis and Abdalla (1995) have used neural networks to predict the global moment versus rotation curve of single web angle beam-to-column joints. Anderson et al. (1997) described the use of neural networks to predict a bilinear approximation of the moment versus rotation curves of minor axis beam-to-column endplate joints. The joints presented in this work

Paper accepted June, 2005. Technical Editor: Atila P. Silva Freire. were not previously used for predicting of the joints behaviour through neural networks.

This work proposes the use of artificial neural networks to predict the flexural resistance $\left(M_{j, R d, A N N}\right)$ and initial stiffness $\left(S_{j, \text { ini,ANN }}\right)$ of semi-rigid beam-to-column joints. This structural engineering problem is characterized by the influence of several physical and geometric parameters and for the great difficulty to generate new data based on experimental tests. This was the main motivation for using artificial neural networks.

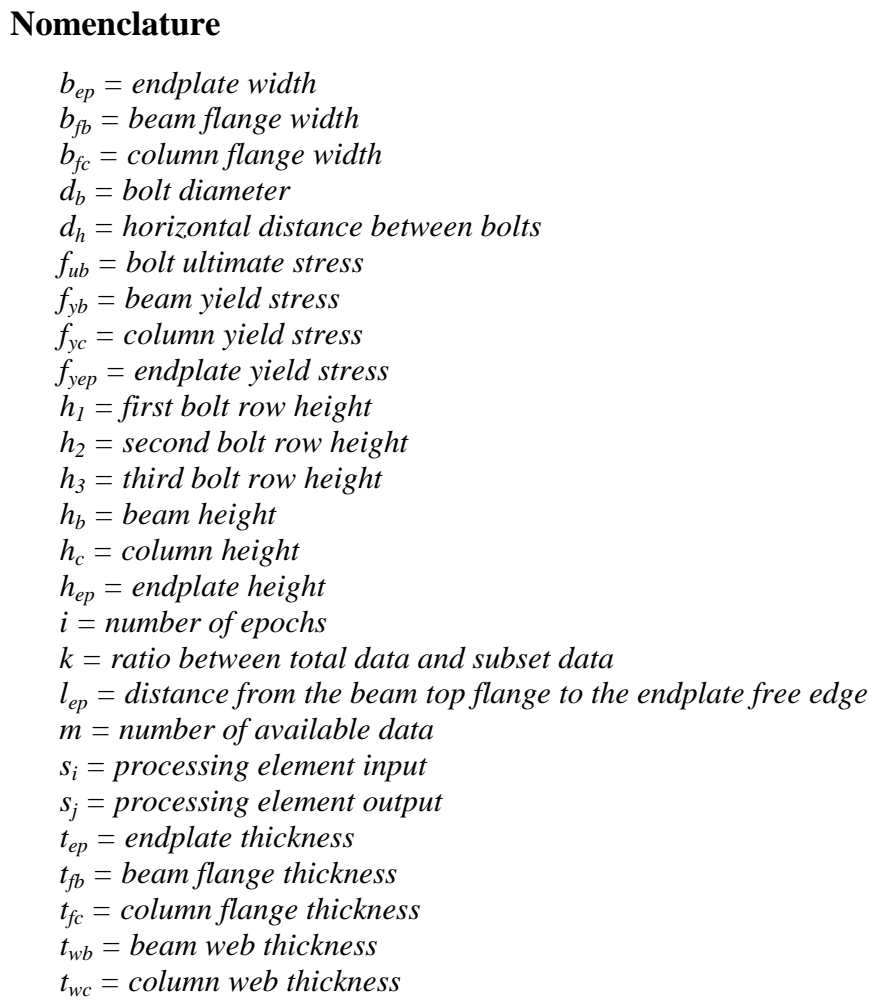


$M_{j . R d}=$ joint flexural resistance

$M_{j, R d, A N N}=$ joint flexural resistance predicted by neural networks

$M_{j, R d, \exp }=$ experimental joint flexural resistance

$M_{j, R d, E C 3}=$ Eurocode 3 joint flexural resistance

$S_{i, i n i}=$ joint initial stiffness

$S_{j, \text { ini,ANN }}=$ joint initial stiffness predicted by neural networks

$S_{j, \text { in, exp }}=$ experimental joint initial stiffness

$S_{j, \text { ini,EC3 }}=$ Eurocode 3 joint initial stiffness

\section{Greek Symbols}

$\phi_{C D}=$ joint rotation capacity

$\alpha=$ momentum factor

$\eta=$ learning rate

\section{The Beam-to-Column Joint Model}

In the present investigation three different types of joints were evaluated by the neural networks. From these studied joints it was possible to identify the bolted end-plate joints as one of the most adopted joints, see Fig. 1. They are widely used in constructional steel design because they can cover a wide range of structural solutions, from pinned to rigid joints, by performing minor geometrical modifications on the joint details.

In general, the required initial stiffness $\left(S_{j, i n i}\right)$ and the bending moment resistance $\left(M_{j, R d}\right)$ of the joint can be obtained using an appropriate configuration of the joint elements, such as number of bolts, endplate thickness and its geometrical configuration. A third variable, the joint rotation capacity $\left(\phi_{C D}\right)$, can also influence the global joint behaviour. Unfortunately, this variable was not easily found in the literature, making difficult its adoption on the artificial neural network prediction model.

The other joints investigated in this analysis were: welded joints and bolted joint with angles shown in Figs. 2 and 3, respectively.

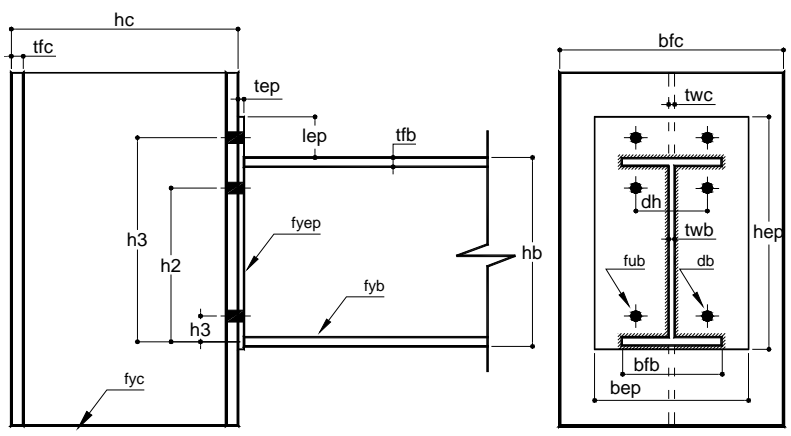

Figure 1. Extended endplate joint layout.

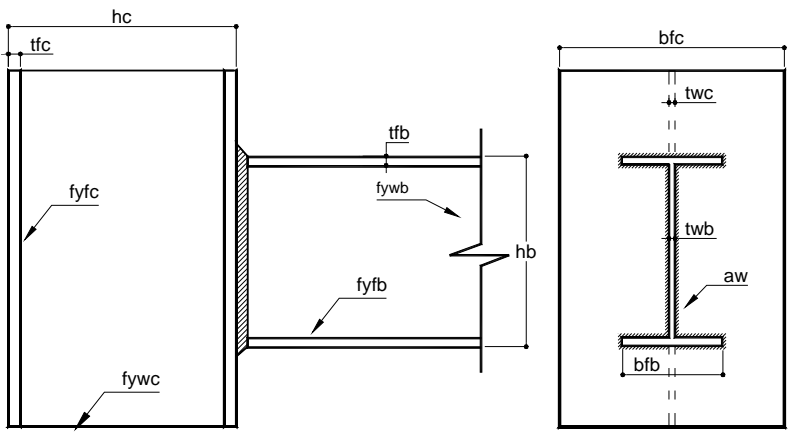

Figure 2. Welded joint layout.

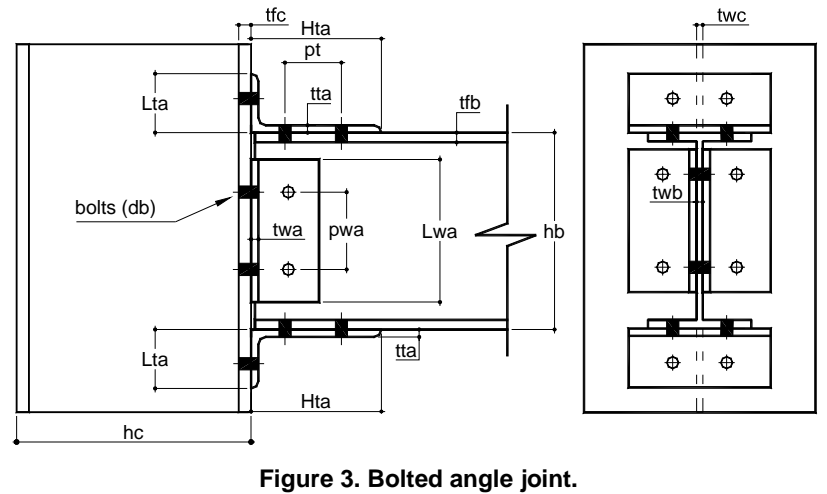

There are several parameters related to the endplate beam-tocolumn joint design. The most significant variables are: column flange thickness $\left(t_{f c}\right)$, column flange width $\left(b_{f c}\right)$, column web thickness $\left(t_{w c}\right)$, column height $\left(h_{c}\right)$, column yield stress $\left(f_{y c}\right)$, beam flange thickness $\left(t_{f b}\right)$, beam flange width $\left(b_{f b}\right)$, beam web thickness $\left(t_{w b}\right)$, beam height $\left(h_{b}\right)$, beam yield stress $\left(f_{y b}\right)$, endplate width $\left(b_{e p}\right)$, endplate height $\left(h_{e p}\right)$, endplate thickness $\left(t_{e p}\right)$, distance from the beam top flange to the endplate free edge $\left(l_{e p}\right)$, endplate yield stress $\left(f_{\text {yep }}\right)$, bolt diameter $\left(d_{b}\right)$, bolt ultimate stress $\left(f_{u b}\right)$, first bolt row height $\left(h_{1}\right)$, second bolt row height $\left(h_{2}\right)$, third bolt row height $\left(h_{3}\right)$ and horizontal distance between bolts $\left(d_{h}\right)$. All these variables are illustrated in Fig. 1. Additional variables utilized to characterize the other two investigated joints, Fig. 2 and 3, are: column flange yield stress $\left(f_{y f c}\right)$, column web yield stress $\left(f_{y w c}\right)$, beam flange yield stress $\left(f_{y f b}\right)$, beam web yield stress $\left(f_{y w b}\right)$, weld thickness $\left(a_{w}\right)$, top and seat angle length $\left(L_{t a}\right)$, top and seat angle height $\left(H_{t a}\right)$, angle thickness $\left(t_{t a}\right)$, horizontal distance between bolts $\left(p_{t}\right)$, web angle thickness $\left(t_{w a}\right)$, vertical distance between bolts $\left(p_{w a}\right)$ and web angle length $\left(L_{w a}\right)$.

The behaviour of beam-to-column joints can also be evaluated with the aid of the component method, largely adopted in research investigations and recently incorporated in European Committee for Standardization - Eurocode 3 (1997). Joint components have been introduced to a simple mechanical model to enable the prediction of beam-to-column moment versus rotation curves (Jaspart, 1997). Fig. 4 depicts an endplate beam-to-column joint together with its associate mechanical model. The mechanical model is composed of rigid links and springs, created to represent each relevant joint component. A comprehensive description of the joint components is presented by Silva and Coelho (2001).

The spring model presented in the Fig. 4 can be simplified by replacing each series of springs by an equivalent elasto-plastic spring, which retains all the relevant characteristics (Silva and Coelho, 2001). Using this procedure, a general non-linear equivalent model for the analysis of beam-to-column joints can also be obtained (Simões et al., 2001). When the equivalent elastic model is defined, the design process continues with a post-buckling stability analysis using an energy-based formulation. Full details of the mathematical derivation can be found in Silva (Silva and Coelho, 2001). Since these procedures are still to be evaluated, the present work uses the bilinear approximation of the moment versus rotation curve related to the joint proposed in Eurocode 3, see Fig. 5. 

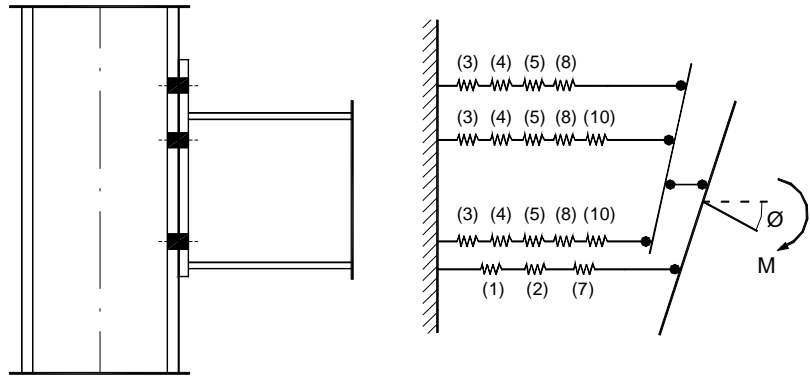

Figure 4. Characterization of the beam-to-column joints components.

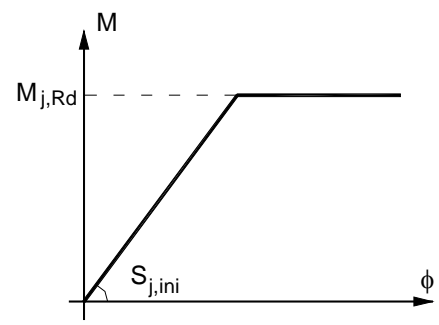

Figure 5. Bilinear approximation of the moment versus rotation curve.

\section{The Proposed Neural Network System}

Artificial neural networks (ANN) are computing systems that simulate the biological neural systems of the human brain (Bishop, 1994 and Haykin, 1999). They are massively parallel systems that rely on simple non-linear processing elements (PE) and dense arrangements of interconnections (Treleavan et al. 1989). These interconnection patterns can range from single-layer, feed-forward networks, like the early Perceptron model, to more complex topologies, formed by multilayers with backward propagation of errors, as in the back propagation model (Rumelhart and McClellan, 1986). These networks have demonstrated their ability to deliver simple and powerful solutions in areas that for many years have challenged conventional computing approaches.

An artificial neural network is represented by weighted interconnection between processing elements (PE). These weights are the parameters that actually define the non-linear function performed by the neural network. The process of determining such parameters is called training or learning and relies on the presentation of many training patterns.

The most widely used neural network learning algorithm is the Back Propagation. This is due to its relatively simplicity, together with its universal approximation capacity (Hornik et al., 1989 and Cybenko, 1989). The Back Propagation algorithm defines a systematic way to update the synaptic weights of multi-layer feedforward supervised networks composed of an input layer, that receives the input values, an output layer, which calculates the neural network output, and one or more intermediary layers, so called hidden layers. The back propagation supervised learning process is based on the gradient descent method that usually minimizes the sum of squared errors between the target value and the output of the neural network.

In this work, the back propagation (BP) learning algorithm has been used, where the network is presented with a set of input vectors and their respective desired output vectors. Two neural networks were used for each joint type, see Fig. 5. The first was used to predict the bending moment resistance while the second was utilized to forecast the joint initial stiffness. The input parameters, represented by the geometric and mechanical characteristics of all the experimental tests, are presented in Tabs. 1, 2 and 3, respectively.

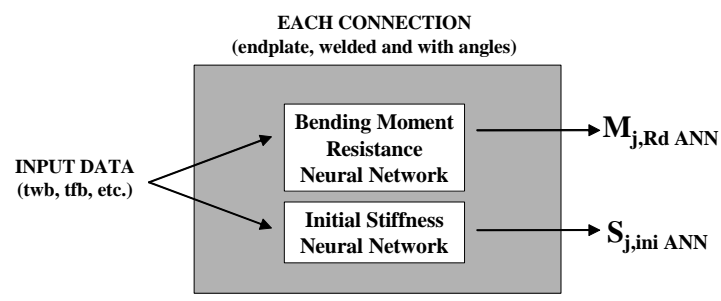

Figure 5. Neural network configurations.

The NeuralWorks Modelling Software (QNet for Windows, 2000) was used to train and test all neural networks. To avoid problems in the training process due to the reduced database, a methodology described by Mitchel (1997) was adopted. In this method, a k-fold cross-validation approach is used, where the $\mathrm{m}$ available examples are partitioned into $\mathrm{k}$ disjoint subsets, each of $\mathrm{m} / \mathrm{k}$ size. The cross-validation procedure is performed $\mathrm{k}$ times, each time using one different subset as the validation set and the other $\mathrm{k}-$ 1 subsets as training set. On each experiment the above crossvalidation approach is used to determine the number of iterations $i$ (epochs) that yield the best performance on the validation set. The mean imean of these estimates for $i$ is then calculated, and a final training of BP is performed with all $\mathrm{m}$ examples for imean iterations, with no validation set.

In this investigation, $m$ was divided into $k=3$ parts (I, II and III), enabling three different validations to be performed. In the first phase, groups I and II are used for training while the validation is made with group III. In the second stage, the training is made with groups I and III and validation is performed with group II. In the last stage, the training is accomplished with groups II and III and the validation is made with group I. Fig. 6 summarizes this procedure.

Several network configurations were tested varying the number of hidden processors (2, 3, 4, 5 and 6). The learning rate was considered adaptive, with an initial value equal to 0.2 while the momentum factor was changed between 0.4 and 0.8 . The optimum Neural Network was obtained through a comparison of the generalization error obtained with the validation set.

The best network configuration for each joint type is presented in Tab. 4, where the number of input patterns, hidden processors, initial and final learning rates $(\eta)$ and the momentum factor $(\alpha)$ are specified for each neural network. 
Table 1. Geometrical characteristics (in $\mathrm{mm}$ ) and mechanical properties (in MPa) for experiments with endplate joints.

\begin{tabular}{|c|c|c|c|c|c|c|c|c|c|c|c|c|c|c|c|c|c|}
\hline ID & Test & $b_{f c}$ & $t_{t_{c}}$ & $h_{c}$ & $f_{y c}$ & $b_{f b}$ & $t_{f b}$ & $h_{b}$ & $f_{y b}$ & $t_{e p}$ & $l_{e p}$ & $f_{\text {yep }}$ & $d_{b}$ & $f_{u b}$ & $h_{1}$ & $h_{2}$ & $d_{h}$ \\
\hline 1 & T110001 & 300 & 13.5 & 296 & 475 & 220.0 & 15.5 & 543.0 & 300 & 25 & 105.0 & 416.0 & 24 & 1323 & 580.3 & 474.8 & 30 \\
\hline 2 & T110002 & 300 & 13.5 & 296 & 482 & 220.0 & 15.5 & 543.0 & 309 & 25 & 105.0 & 410.0 & 24 & 1323 & 580.3 & 474.8 & 30 \\
\hline 3 & T110005 & 300 & 12.5 & 296 & 532 & 220.0 & 15.5 & 547.0 & 290 & 25 & 105.0 & 404.0 & 24 & 1323 & 584.2 & 478.8 & 30 \\
\hline 4 & T109003 & 180 & 14.1 & 179 & 300 & 151.0 & 11.2 & 300.0 & 323 & 30 & 70.0 & 273.0 & 20 & 1000 & 334.4 & 244.4 & 46 \\
\hline 5 & T109004 & 180 & 14.0 & 180 & 306 & 192.0 & 14.0 & 454.0 & 285 & 41 & 84.0 & 323.0 & 24 & 1000 & 496.0 & 381.0 & 65 \\
\hline 6 & T109006 & 240 & 17.0 & 240 & 275 & 220.0 & 18.6 & 597.0 & 288 & 41 & 82.0 & 325.0 & 24 & 1000 & 634.7 & 514.7 & 62 \\
\hline 7 & T101007 & 163 & 12.6 & 160 & 280 & 99.7 & 8.4 & 198.8 & 351 & 15 & 60.0 & 315.5 & 16 & 1000 & 229.6 & 149.6 & 25 \\
\hline 8 & T101010 & 160 & 12.6 & 163 & 280 & 150.9 & 10.8 & 298.9 & 303 & 20 & 70.0 & 291.5 & 20 & 1000 & 333.5 & 243.5 & 30 \\
\hline 9 & T101013 & 120 & 9.7 & 241 & 310 & 99.7 & 8.4 & 198.8 & 351 & 18 & 60.0 & 330.5 & 16 & 1000 & 229.6 & 149.6 & 24 \\
\hline 10 & T101014 & 151 & 10.8 & 299 & 303 & 99.7 & 8.4 & 198.8 & 351 & 15 & 60.0 & 327.0 & 16 & 1000 & 229.6 & 149.6 & 25 \\
\hline 11 & T839 & 240 & 12.0 & 230 & 256 & 180.0 & 13.5 & 400.0 & 235 & 12 & 80.0 & 214.0 & 20 & 785 & 433.3 & 343.3 & 35 \\
\hline 12 & T8310 & 200 & 15.0 & 200 & 243 & 180.0 & 13.5 & 400.0 & 235 & 14 & 80.0 & 312.0 & 20 & 980 & 433.3 & 343.3 & 35 \\
\hline 13 & T8311 & 300 & 14.0 & 290 & 417 & 300.0 & 23.0 & 490.0 & 235 & 14 & 113.0 & 312.0 & 24 & 785 & 546.5 & 426.5 & 60 \\
\hline 14 & T911 & 301 & 14.4 & 302 & 317 & 181.0 & 14.6 & 401.0 & 323 & 30 & 90.0 & 266.0 & 24 & 980 & 443.7 & 338.7 & 61 \\
\hline 15 & T913 & 301 & 14.5 & 301 & 279 & 181.0 & 14.4 & 401.0 & 279 & 30 & 90.0 & 239.5 & 24 & 980 & 443.8 & 338.8 & 61 \\
\hline 16 & TC5 & 204 & 10.9 & 206 & 283 & 133.3 & 7.6 & 205.4 & 283 & 16 & 111.2 & 250.0 & 16 & 633 & 268.8 & 138.8 & 30 \\
\hline 17 & TC6 & 204 & 10.9 & 206 & 283 & 133.3 & 7.6 & 205.4 & 283 & 16 & 111.2 & 250.0 & 20 & 980 & 268.8 & 138.8 & 30 \\
\hline 18 & TC7 & 204 & 10.9 & 206 & 283 & 133.3 & 7.6 & 205.4 & 283 & 20 & 111.2 & 250.0 & 16 & 633 & 268.8 & 138.8 & 30 \\
\hline 19 & TC8 & 204 & 10.9 & 206 & 283 & 133.3 & 7.6 & 205.4 & 283 & 20 & 111.2 & 250.0 & 20 & 980 & 268.8 & 138.8 & 30 \\
\hline 20 & TC9 & 204 & 10.9 & 206 & 283 & 133.3 & 7.6 & 205.4 & 283 & 16 & 111.2 & 250.0 & 16 & 633 & 268.8 & 138.8 & 30 \\
\hline 21 & TC11 & 204 & 10.9 & 206 & 283 & 133.3 & 7.6 & 205.4 & 283 & 20 & 111.2 & 250.0 & 16 & 633 & 268.8 & 138.8 & 30 \\
\hline 22 & T109005 & 240 & 16.4 & 240 & 276 & 192.0 & 14.0 & 454.0 & 285 & 41 & 84.0 & 323.0 & 24 & 1000 & 496.0 & 381.0 & 65 \\
\hline 23 & T101004 & 160 & 12.6 & 163 & 280 & 99.7 & 8.4 & 198.8 & 351 & 15 & 60.0 & 315.5 & 16 & 1000 & 229.6 & 149.6 & 25 \\
\hline 24 & T912 & 301 & 14.3 & 302 & 317 & 181.0 & 14.4 & 401.0 & 317 & 30 & 90.0 & 261.0 & 24 & 980 & 443.8 & 338.8 & 61 \\
\hline 25 & TC10 & 204 & 10.9 & 206 & 283 & 133.3 & 7.6 & 205.4 & 283 & 16 & 111.2 & 250.0 & 20 & 980 & 268.8 & 138.8 & 30 \\
\hline 26 & TC12 & 204 & 10.9 & 206 & 283 & 133.3 & 7.6 & 205.4 & 283 & 20 & 111.2 & 250.0 & 20 & 980 & 268.8 & 138.8 & 30 \\
\hline
\end{tabular}

Table 2. Geometrical characteristics (in $\mathrm{mm}$ ) and mechanical properties (in MPa) for the experiments with welded joints.

\begin{tabular}{|c|c|c|c|c|c|c|c|c|c|c|c|}
\hline ID & Test & $b_{f c}$ & $t_{f c}$ & $t_{w c}$ & $h_{c}$ & $f_{y f c}$ & $b_{f b}$ & $t_{f b}$ & $h_{b}$ & $f_{y f b}$ & $a_{w}$ \\
\hline 1 & T107001 & 178 & 8.9 & 6.2 & 173 & 334.6 & 119 & 10.2 & 238 & 389.8 & 6.8 \\
\hline 2 & T107002 & 179 & 8.8 & 6.2 & 175 & 342.5 & 149 & 10.0 & 300 & 306.2 & 5.8 \\
\hline 3 & T107003 & 242 & 10.7 & 9.4 & 233 & 354.2 & 149 & 10.0 & 300 & 304.8 & 9.1 \\
\hline 4 & T105002 & 160 & 13.3 & 7.6 & 159 & 260.0 & 162 & 11.4 & 328 & 286.0 & 7.5 \\
\hline 5 & T105003 & 179 & 13.5 & 9.0 & 183 & 288.0 & 149 & 10.0 & 298 & 334.0 & 7.0 \\
\hline 6 & T105005 & 200 & 13.9 & 8.4 & 202 & 273.0 & 171 & 10.7 & 361 & 271.0 & 7.2 \\
\hline 7 & T105006 & 239 & 16.0 & 9.7 & 239 & 276.0 & 223 & 18.1 & 604 & 306.0 & 10.3 \\
\hline 8 & T105008 & 301 & 19.3 & 12.4 & 297 & 292.0 & 300 & 17.8 & 301 & 357.0 & 13.0 \\
\hline 9 & T105009 & 139 & 11.5 & 7.7 & 139 & 300.0 & 110 & 10.0 & 218 & 312.0 & 6.2 \\
\hline 10 & T105010 & 138 & 11.6 & 7.8 & 146 & 281.0 & 111 & 9.1 & 221 & 361.0 & 6.2 \\
\hline 11 & T105011 & 140 & 12.0 & 7.5 & 142 & 298.0 & 151 & 11.1 & 302 & 304.0 & 6.4 \\
\hline 12 & T105014 & 178 & 13.7 & 8.1 & 177 & 292.0 & 170 & 12.3 & 359 & 290.0 & 7.5 \\
\hline 13 & T105015 & 179 & 13.5 & 9.4 & 178 & 275.0 & 180 & 12.5 & 397 & 290.0 & 10.2 \\
\hline 14 & T105016 & 200 & 14.6 & 9.4 & 200 & 279.0 & 171 & 12.0 & 361 & 273.0 & 8.9 \\
\hline 15 & T105019 & 239 & 16.3 & 10.1 & 240 & 274.0 & 224 & 18.7 & 605 & 322.0 & 8.6 \\
\hline 16 & T105020 & 299 & 18.3 & 10.8 & 298 & 301.0 & 210 & 17.2 & 551 & 268.0 & 11.9 \\
\hline 17 & T105021 & 299 & 18.9 & 12.3 & 303 & 266.0 & 220 & 19.4 & 600 & 268.0 & 11.6 \\
\hline 18 & T105023 & 301 & 18.7 & 12.0 & 302 & 276.0 & 299 & 22.9 & 402 & 281.0 & 12.1 \\
\hline 19 & T105025 & 301 & 21.3 & 11.9 & 361 & 276.0 & 224 & 18.2 & 604 & 316.0 & 11.4 \\
\hline 20 & T106001 & 145 & 21.4 & 13.2 & 159 & 283.0 & 149 & 11.0 & 295 & 358.0 & 11.8 \\
\hline 21 & T106003 & 204 & 25.4 & 15.9 & 221 & 268.0 & 180 & 12.6 & 401 & 265.0 & 11.0 \\
\hline 22 & T106004 & 204 & 25.6 & 15.9 & 222 & 267.0 & 199 & 15.1 & 498 & 248.0 & 14.0 \\
\hline 23 & T106005 & 204 & 24.5 & 16.0 & 222 & 280.0 & 224 & 18.7 & 600 & 277.0 & 12.7 \\
\hline 24 & T106006 & 222 & 25.0 & 16.5 & 241 & 278.0 & 209 & 18.0 & 552 & 361.0 & 13.5 \\
\hline 25 & T106007 & 308 & 37.0 & 21.2 & 340 & 237.0 & 300 & 28.0 & 603 & 262.0 & 14.2 \\
\hline 26 & T108032 & 199 & 15.0 & 9.0 & 199 & 370.0 & 186 & 13.1 & 450 & 386.0 & 4.0 \\
\hline 27 & T108038 & 202 & 12.0 & 8.7 & 209 & 291.0 & 168 & 12.5 & 361 & 307.0 & 5.5 \\
\hline 28 & T107004 & 242 & 10.8 & 11.3 & 233 & 343.9 & 190 & 13.2 & 452 & 287.0 & 11.3 \\
\hline 29 & T105004 & 179 & 13.4 & 8.2 & 183 & 277.0 & 180 & 12.3 & 398 & 284.0 & 9.3 \\
\hline 30 & T105007 & 299 & 18.6 & 11.7 & 300 & 296.0 & 181 & 13.2 & 400 & 309.0 & 9.1 \\
\hline 31 & T105018 & 240 & 16.1 & 9.7 & 239 & 269.0 & 189 & 14.1 & 451 & 284.0 & 10.1 \\
\hline 32 & T105024 & 300 & 18.0 & 10.6 & 298 & 271.0 & 301 & 27.6 & 500 & 271.0 & 12.7 \\
\hline 33 & T106002 & 186 & 22.8 & 14.5 & 200 & 265.0 & 177 & 13.5 & 398 & 358.0 & 12.1 \\
\hline 34 & T108042 & 255 & 18.5 & 12.2 & 265 & 267.0 & 200 & 15.5 & 498 & 288.0 & 5.7 \\
\hline
\end{tabular}


The NeuralWorks Modelling Software (QNet for Windows, 2000) was used to train and test all neural networks. To avoid problems in the training process due to the reduced database, a methodology described by Mitchel (1997) was adopted. In this method, a k-fold cross-validation approach is used, where the $m$ available examples are partitioned into $k$ disjoint subsets, each of $\mathrm{m} / \mathrm{k}$ size. The cross-validation procedure is performed $\mathrm{k}$ times, each time using one different subset as the validation set and the other $k-$ 1 subsets as training set. On each experiment the above crossvalidation approach is used to determine the number of iterations $\mathrm{i}$ (epochs) that yield the best performance on the validation set. The mean $i_{\text {mean }}$ of these estimates for $\mathrm{i}$ is then calculated, and a final training of BP is performed with all m examples for $i_{\text {mean }}$ iterations, with no validation set.

In this investigation, $m$ was divided into $k=3$ parts (I, II and III), enabling three different validations to be performed. In the first phase, groups I and II are used for training while the validation is made with group III. In the second stage, the training is made with groups I and III and validation is performed with group II. In the last stage, the training is accomplished with groups II and III and the validation is made with group I. Fig. 6 summarizes this procedure.

Several network configurations were tested varying the number of hidden processors (2, 3, 4, 5 and 6). The learning rate was considered adaptive, with an initial value equal to 0.2 while the momentum factor was changed between 0.4 and 0.8 . The optimum Neural Network was obtained through a comparison of the generalization error obtained with the validation set.

The best network configuration for each joint type is presented in Tab. 4, where the number of input patterns, hidden processors, initial and final learning rates $(\eta)$ and the momentum factor $(\alpha)$ are specified for each neural network.

Table 3. Geometrical characteristics (in $\mathrm{mm}$ ) for the experiments with bolted joint with angles.

\begin{tabular}{|c|c|c|c|c|c|c|c|}
\hline ID & Test & $\mathrm{t}_{\mathrm{fc}}$ & $\mathrm{h}_{\mathrm{b}}$ & $\mathrm{t}_{\mathrm{ta}}$ & $\mathrm{L}_{\mathrm{ta}}$ & $\mathrm{L}_{\mathrm{wa}}$ & $\mathrm{d}_{\mathrm{b}}$ \\
\hline 1 & $8 \mathrm{~S} 1$ & 16.3 & 209.6 & 9.5 & 88.9 & 139.7 & 16.0 \\
\hline 2 & $8 \mathrm{~S} 2$ & 16.3 & 209.6 & 9.5 & 88.9 & 139.7 & 16.0 \\
\hline 3 & $8 \mathrm{~S} 3$ & 16.3 & 209.6 & 7.9 & 88.9 & 139.7 & 16.0 \\
\hline 4 & $8 \mathrm{~S} 4$ & 16.3 & 209.6 & 9.5 & 152.4 & 139.7 & 16.0 \\
\hline 5 & $8 \mathrm{~S} 5$ & 16.3 & 209.6 & 9.5 & 101.6 & 139.7 & 16.0 \\
\hline 6 & $8 S 6$ & 16.3 & 209.6 & 7.9 & 101.6 & 139.7 & 16.0 \\
\hline 7 & $8 S 7$ & 16.3 & 209.6 & 9.5 & 101.6 & 139.7 & 16.0 \\
\hline 8 & $8 S 10$ & 16.3 & 209.6 & 12.7 & 88.9 & 139.7 & 22.2 \\
\hline 9 & 14S1 & 22.9 & 358.8 & 9.5 & 101.6 & 215.9 & 16.0 \\
\hline 10 & $14 S 2$ & 22.9 & 358.8 & 12.7 & 101.6 & 215.9 & 16.0 \\
\hline 11 & 14S4 & 22.9 & 358.8 & 9.5 & 101.6 & 215.9 & 16.0 \\
\hline 12 & 14S5 & 22.9 & 358.8 & 9.5 & 101.6 & 215.9 & 22.2 \\
\hline 13 & $14 S 6$ & 22.9 & 358.8 & 12.7 & 101.6 & 215.9 & 22.2 \\
\hline 14 & 14S8 & 22.9 & 358.8 & 15.9 & 101.6 & 215.9 & 22.2 \\
\hline 15 & $8 S 8$ & 16.3 & 209.6 & 7.9 & 88.9 & 139.7 & 22.2 \\
\hline 16 & $8 S 9$ & 16.3 & 209.6 & 9.5 & 88.9 & 139.7 & 22.2 \\
\hline 17 & 14S3 & 22.9 & 358.8 & 9.5 & 101.6 & 139.7 & 16.0 \\
\hline 18 & 14S9 & 22.9 & 358.8 & 12.7 & 101.6 & 215.9 & 22.2 \\
\hline
\end{tabular}

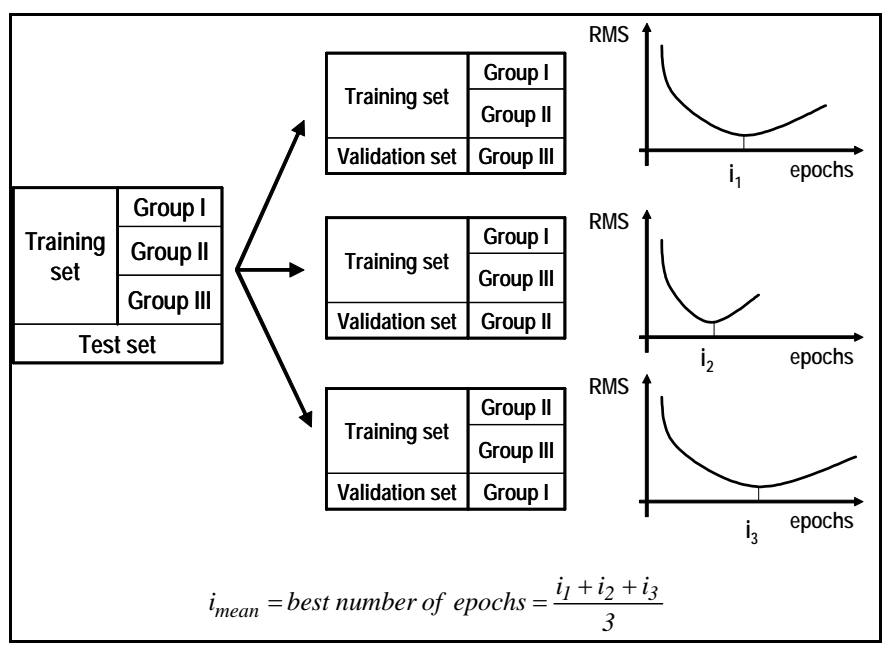

Figure 6. Cross-validation methodology used due to the reduced training database.
Table 4. Neural networks configurations.

\begin{tabular}{|l|c|c|c|c|c|c|}
\hline Joint type & \multicolumn{2}{|c|}{ Endplate } & \multicolumn{2}{c|}{ Welded } & \multicolumn{2}{c|}{ Angles } \\
\hline $\begin{array}{l}\text { Number of } \\
\text { patterns }\end{array}$ & \multicolumn{2}{|c|}{26} & \multicolumn{2}{c|}{33} & \multicolumn{2}{c|}{18} \\
\hline Training data & \multicolumn{2}{|c|}{21} & \multicolumn{2}{c|}{26} & \multicolumn{2}{c|}{14} \\
\hline Test data & \multicolumn{2}{|c|}{5} & \multicolumn{2}{c|}{7} & \multicolumn{2}{c|}{4} \\
\hline & $M_{j, R d}$ & $S_{j, \text { inii }}$ & $M_{j, R d}$ & $S_{j, \text { ini }}$ & $M_{j, R d}$ & $S_{j, \text { ini }}$ \\
\hline Hidden layers & 1 & 1 & 1 & 1 & 1 & 1 \\
\hline $\begin{array}{l}\text { Processors in } \\
\text { each hidden } \\
\text { layer }\end{array}$ & 3 & 4 & 6 & 3 & 5 & 5 \\
\hline $\begin{array}{l}\text { Initial learning } \\
\text { rate }(\eta)\end{array}$ & 0.3 & 0.3 & 0.3 & 0.3 & 0.3 & 0.3 \\
\hline $\begin{array}{l}\text { Final learning } \\
\text { rate }(\eta)\end{array}$ & 0.28 & 0.25 & 0.27 & 0.28 & 0.28 & 0.28 \\
\hline Momentum $(\alpha)$ & 0.6 & 0.6 & 0.6 & 0.6 & 0.6 & 0.6 \\
\hline
\end{tabular}




\section{Neural Network Results}

\section{Bolted Endplate Joints Results}

For this type of joint, the results of 26 experimental tests (21 for training and 5 for testing) were used, producing satisfactory results for the prediction of the flexural resistance where the mean absolute percent error (MAPE) was 8.4\%. The minimum and maximum percentile errors were $-15.5 \%$ and $18 \%$. For the prediction of the initial stiffness, the obtained values weren't so good. The mean error was $23.5 \%$ while $-33.8 \%$ and $38.3 \%$ represent the minimum and maximum percentile errors.

Figure 7 illustrates a comparison of the ratio between the values predicted by the neural networks, the Eurocode 3 formulae, and the experimental values. In the sequence, a similar comparison for the joint initial stiffness is presented in the Figure 8.

It can be observed that the performance obtained in the prediction of flexural resistance was significantly better than the initial stiffness prediction. The initial stiffness prediction pointed out for the significant importance of obtaining new experimental data. Both results are summarized in Tabs. 5 and 6, respectively.

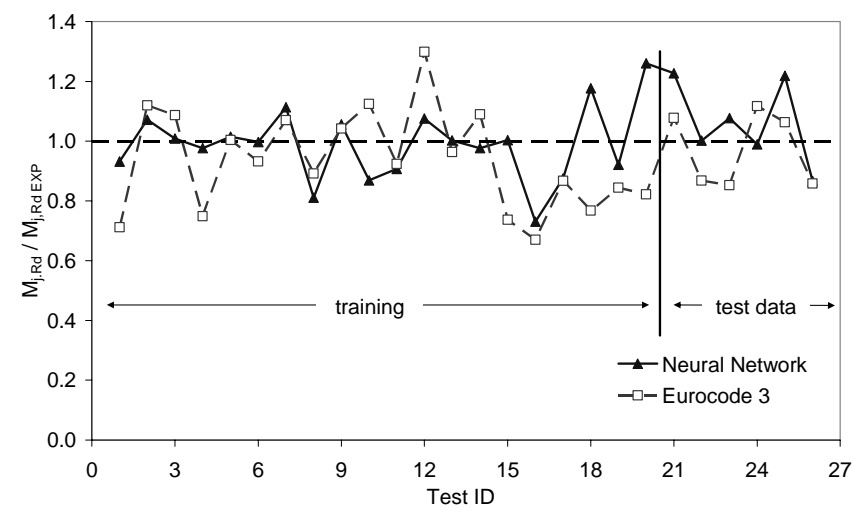

Figure 7. Flexural resistance relative comparison for endplate joints.

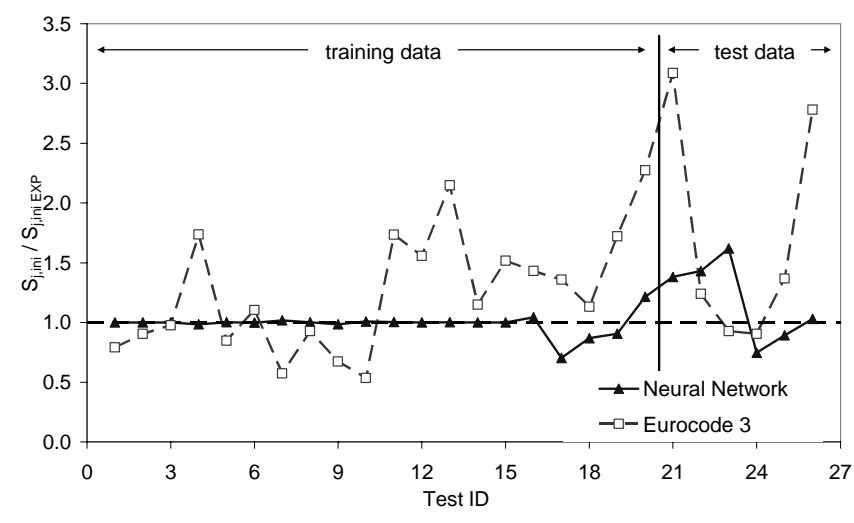

Figure 8. Initial stiffness relative comparison for endplate joints.

\section{Welded Joints Results}

Figure 9 depicts the comparison of the results obtained with NN and Eurocode 3 formulae for the welded joint flexural resistance. From this graph it is possible to conclude that the neural network results reached a good agreement with the joints experimental values, while the Eurocode 3 prediction values conducted to misleading results. The mean neural network error was $8.9 \%$ with
$-5.4 \%$ and $12.4 \%$ of minimum and maximum percentile error values, respectively.



Figure 9. Flexural resistance relative comparison for welded joints.

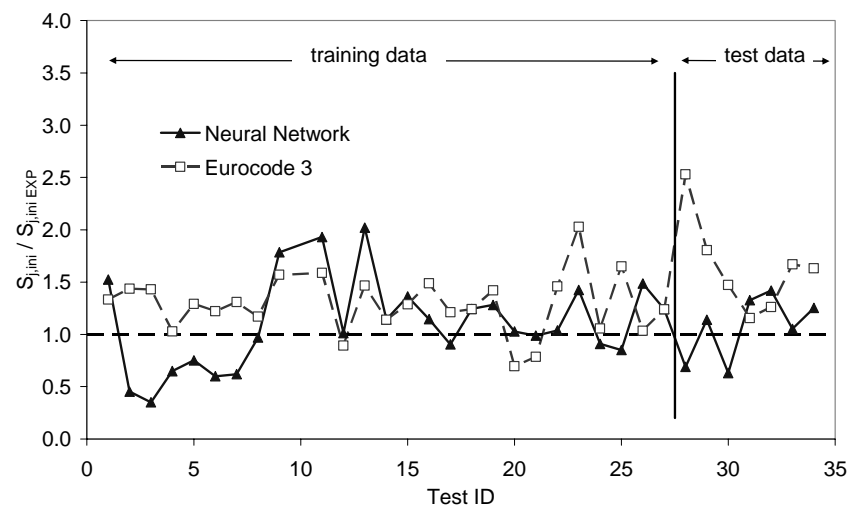

Figure 10. Initial stiffness relative comparison for welded joints.

Figure 10 depicts the welded joint initial stiffness results. The mean error was $28 \%$ with $-58.4 \%$ and $30 \%$ of minimum and maximum percentile error values respectively. Again, the obtained initial stiffness results were not as good as the moment prediction values but it is fair to mention that the values from Eurocode 3 formulae also did not present a good agreement with the experimental data. The summary of the obtained results is presented in Tabs. 7 and 8.

\section{Bolted Joints with Angles Results}

Figure 11 presents the results obtained for bolted joints with angles. For flexural resistance results, the mean error was $11.6 \%$ with $-18.3 \%$ and $4.7 \%$ of minimum and maximum percentile error values, respectively. The results for the initial stiffness prediction presented in Figure 12 led to the conclusion that neural network results were more accurate than the values obtained from the theoretical analysis evaluated by Kishi \& Chen formulation, [12] and [13].

The potential of the neural networks to predict the joints ultimate moment and initial stiffness was confirmed by these graphs. Although some of the neural network initial stiffness values differ up to $59 \%$ from the experiments, this can be explained by the difficulties in the laboratory measuring devices and associated experimental errors, which can produce misleading values for the experimental test results. The summary of the obtained results is presented in Tabs. 9 and 10. 


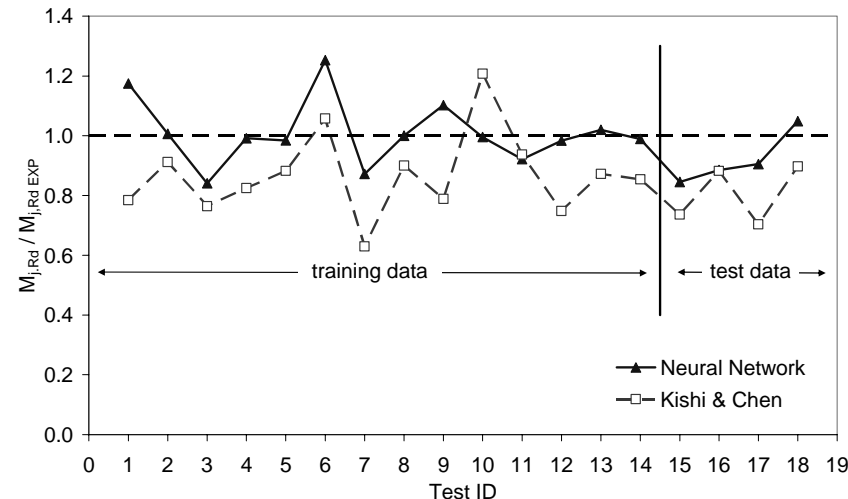

Figure 11. Flexural resistance relative comparison for bolted joints with angles.

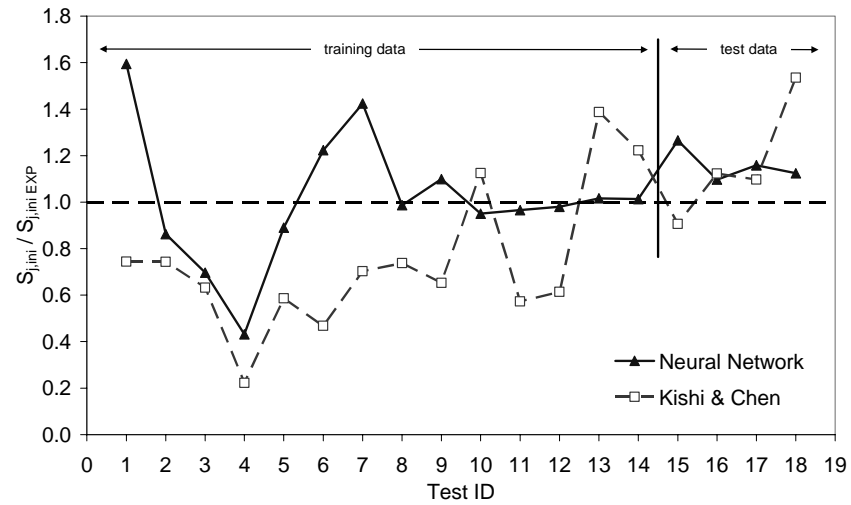

Figure 12. Initial stiffness relative comparison for bolted joints with angles.

Table 5. Flexural resistance comparison for endplate joints.

\begin{tabular}{|c|c|c|c|c|c|c|c|}
\hline Test & & Author & $M_{j, R d E X P}(\mathrm{kN} . \mathrm{m})$ & $M_{j, R d \text { ANN }}(\mathrm{kN} . \mathrm{m})$ & $\begin{array}{c}\mathrm{M}_{\mathrm{j}, \mathrm{Rd} \text { ANN }} / \\
\mathrm{M}_{\mathrm{j}, \mathrm{Rd} \text { EXP }}\end{array}$ & $\begin{array}{c}M_{j R d \text { EC3 }} \\
\text { (kN.m) }\end{array}$ & $\begin{array}{c}M_{j R d E C 3} \\
M_{j, R d E X P}\end{array}$ \\
\hline T110001 & \multirow{21}{*}{ 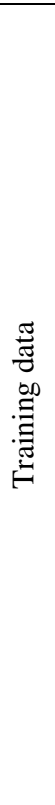 } & Faella et al. (1999) & 785.0 & 731.4 & 0.93 & 558.84 & 0.71 \\
\hline T110002 & & Faella et al. (1999) & 488.7 & 523.8 & 1.07 & 547.27 & 1.12 \\
\hline T110005 & & Faella et al. (1999) & 535.0 & 539.5 & 1.01 & 581.20 & 1.09 \\
\hline T109003 & & Hummer and Tschemmernegg & 155.1 & 151.4 & 0.98 & 116.12 & 0.75 \\
\hline T109004 & & Hummer and Tschemmernegg & 188.1 & 190.9 & 1.01 & 188.90 & 1.00 \\
\hline T109006 & & Hummer and Tschemmernegg & 354.7 & 353.6 & 1.00 & 330.62 & 0.93 \\
\hline T101007 & & Janss et al. (1987) & 52.6 & 58.5 & 1.11 & 56.25 & 1.07 \\
\hline T101010 & & Janss et al. (1987) & 96.4 & 78.2 & 0.81 & 85.95 & 0.89 \\
\hline T101013 & & Janss et al. (1987) & 51.0 & 53.9 & 1.06 & 53.19 & 1.04 \\
\hline T101014 & & Janss et al. (1987) & 50.6 & 44.0 & 0.87 & 56.86 & 1.12 \\
\hline T839 & & Zoetemeijer and Hunter (1983) & 99.2 & 90.1 & 0.91 & 91.71 & 0.92 \\
\hline T8310 & & Zoetemeijer and Hunter (1983) & 127.8 & 137.5 & 1.08 & 166.01 & 1.30 \\
\hline T8311 & & Zoetemeijer and Hunter (1983) & 231.3 & 231.8 & 1.00 & 222.70 & 0.96 \\
\hline T911 & & Simek and Wald (1991) & 196.9 & 192.3 & 0.98 & 214.57 & 1.09 \\
\hline T913 & & Simek and Wald (1991) & 392.0 & 393.3 & 1.00 & 288.72 & 0.74 \\
\hline TC5 & & Aggarwal (1994) & 70.5 & 51.5 & 0.73 & 47.21 & 0.67 \\
\hline TC6 & & Aggarwal (1994) & 63.1 & 55.2 & 0.88 & 54.68 & 0.87 \\
\hline TC7 & & Aggarwal (1994) & 61.5 & 72.4 & 1.18 & 47.21 & 0.77 \\
\hline TC9 & & Aggarwal (1994) & 55.9 & 51.5 & 0.92 & 47.21 & 0.84 \\
\hline TC11 & & Aggarwal (1994) & 57.5 & 72.4 & 1.26 & 47.21 & 0.82 \\
\hline TC12 & & Aggarwal (1994) & 62.8 & 77.0 & 1.23 & 67.68 & 1.08 \\
\hline T109005 & \multirow{5}{*}{ 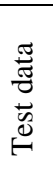 } & Hummer and Tschemmernegg & 311.7 & 312.2 & 1.00 & 270.60 & 0.87 \\
\hline T101004 & & Janss et al. (1987) & 54.1 & 58.2 & 1.08 & 46.07 & 0.85 \\
\hline T912 & & Simek and Wald (1991) & 200.0 & 197.8 & 0.99 & 223.46 & 1.12 \\
\hline TC8 & & Aggarwal (1994) & 63.2 & 77.0 & 1.22 & 67.22 & 1.06 \\
\hline TC10 & & Aggarwal (1994) & 63.8 & 55.2 & 0.87 & 54.68 & 0.86 \\
\hline
\end{tabular}


Table 6. Initial stiffness comparison for endplate joints.

\begin{tabular}{|c|c|c|c|c|c|c|c|}
\hline Test & & Author & $\begin{array}{l}S_{\text {j,ini EXP }} \\
\text { (kN.m) }\end{array}$ & $\begin{array}{c}S_{j, \text { ini } A N N} \\
(\mathrm{kN} . \mathrm{m} / \mathrm{rad})\end{array}$ & $\begin{array}{c}S_{j, \text { ini ANN }} / \\
S_{j, \text { ini EXP }} \\
\end{array}$ & $\begin{array}{c}S_{\text {j,ini } E C 3} \\
(\mathrm{kN} . \mathrm{m} / \mathrm{rad})\end{array}$ & $\begin{array}{c}S_{j, \text { ini ECS }} / \\
S_{j, \text { ini EXP }} \\
\end{array}$ \\
\hline T110001 & \multirow{21}{*}{ 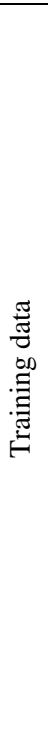 } & Faella et al. (1999) & 490385 & 490355 & 1.00 & 388345 & 0.79 \\
\hline T110002 & & Faella et al. (1999) & 137937 & 137933 & 1.00 & 124638 & 0.90 \\
\hline T110005 & & Faella et al. (1999) & 135149 & 135166 & 1.00 & 131893 & 0.98 \\
\hline T109003 & & Hummer and Tschemmernegg & 18746 & 18450 & 0.98 & 32573 & 1.74 \\
\hline T109004 & & Hummer and Tschemmernegg & 74135 & 74279 & 1.00 & 62759 & 0.85 \\
\hline T109006 & & Hummer and Tschemmernegg & 115704 & 115461 & 1.00 & 127783 & 1.10 \\
\hline T101007 & & Janss et al. (1987) & 21276 & 21668 & 1.02 & 12198 & 0.57 \\
\hline T101010 & & Janss et al. (1987) & 25316 & 25371 & 1.00 & 23471 & 0.93 \\
\hline T101013 & & Janss et al. (1987) & 12739 & 12533 & 0.98 & 8569 & 0.67 \\
\hline T101014 & & Janss et al. (1987) & 16161 & 16284 & 1.01 & 8627 & 0.53 \\
\hline T839 & & Zoetemeijer and Hunter (1983) & 33098 & 33249 & 1.00 & 57428 & 1.74 \\
\hline T8310 & & Zoetemeijer and Hunter (1983) & 52222 & 52240 & 1.00 & 81296 & 1.56 \\
\hline T8311 & & Zoetemeijer and Hunter (1983) & 29375 & 29461 & 1.00 & 63079 & 2.15 \\
\hline T911 & & Simek and Wald (1991) & 55294 & 55293 & 1.00 & 63578 & 1.15 \\
\hline T913 & & Simek and Wald (1991) & 85454 & 85555 & 1.00 & 129702 & 1.52 \\
\hline TC5 & & Aggarwal (1994) & 6183 & 6455 & 1.04 & 8848 & 1.43 \\
\hline TC6 & & Aggarwal (1994) & 6680 & 4704 & 0.70 & 9069 & 1.36 \\
\hline TC7 & & Aggarwal (1994) & 8600 & 7470 & 0.87 & 9729 & 1.13 \\
\hline TC9 & & Aggarwal (1994) & 7125 & 6455 & 0.91 & 12264 & 1.72 \\
\hline TC11 & & Aggarwal (1994) & 6150 & 7470 & 1.21 & 13983 & 2.27 \\
\hline TC12 & & Aggarwal (1994) & 4730 & 6533 & 1.38 & 14607 & 3.09 \\
\hline T109005 & \multirow{5}{*}{ 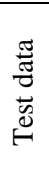 } & Hummer and Tschemmernegg & 67915 & 97192 & 1.43 & 84194 & 1.24 \\
\hline T101004 & & Janss et al. (1987) & 13289 & 21528 & 1.62 & 12321 & 0.93 \\
\hline T912 & & Simek and Wald (1991) & 72308 & 54025 & 0.75 & 65353 & 0.90 \\
\hline TC8 & & Aggarwal (1994) & 7330 & 6533 & 0.89 & 10026 & 1.37 \\
\hline TC10 & & Aggarwal (1994) & 4565 & 4704 & 1.03 & 12694 & 2.78 \\
\hline
\end{tabular}

Table 7. Flexural resistance comparison for welded joints.

\begin{tabular}{|c|c|c|c|c|c|c|c|}
\hline Test & & Author & $M_{j, R d E X P} \quad(\mathrm{kN} . \mathrm{m})$ & $M_{j, R d \text { ANN }}$ & $\begin{array}{c}\mathrm{M}_{\mathrm{j}, \mathrm{Rd} \text { ANN }} / \\
\mathrm{M}_{\mathrm{j}, \mathrm{Rd} \text { EXP }} \\
\end{array}$ & $M_{j R d E C 3} \quad(\mathrm{kN} . \mathrm{m})$ & $\begin{array}{c}M_{j R d E C 3} /_{\text {EXP }} \\
\end{array}$ \\
\hline T107001 & \multirow{26}{*}{ 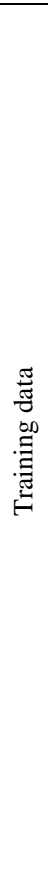 } & \multirow{26}{*}{$\begin{array}{c}\text { Not } \\
\text { available }\end{array}$} & 71.2 & 74.3 & 1.04 & 71.2 & 1.00 \\
\hline T107002 & & & 97.3 & 104.6 & 1.08 & 86.0 & 0.88 \\
\hline T107003 & & & 161.2 & 156.7 & 0.97 & 111.6 & 0.69 \\
\hline T105003 & & & 102.4 & 93.7 & 0.92 & 128.4 & 1.25 \\
\hline T105004 & & & 190.8 & 176.0 & 0.92 & 177.9 & 0.93 \\
\hline T105005 & & & 185.6 & 191.6 & 1.03 & 143.9 & 0.78 \\
\hline T105006 & & & 445.4 & 419.3 & 0.94 & 394.6 & 0.89 \\
\hline T105008 & & & 244.8 & 246.5 & 1.01 & 335.1 & 1.37 \\
\hline T105009 & & & 60.6 & 56.9 & 0.94 & 53.9 & 0.89 \\
\hline T105011 & & & 82.4 & 88.2 & 1.07 & 85.7 & 1.04 \\
\hline T105014 & & & 119.8 & 120.2 & 1.00 & 139.3 & 1.16 \\
\hline T105015 & & & 153.0 & 149.0 & 0.97 & 173.0 & 1.13 \\
\hline T105016 & & & 131.4 & 150.3 & 1.14 & 168.8 & 1.28 \\
\hline T105019 & & & 323.6 & 349.0 & 1.08 & 366.7 & 1.13 \\
\hline T105020 & & & 512.4 & 518.0 & 1.01 & 474.7 & 0.93 \\
\hline T105021 & & & 488.4 & 496.1 & 1.02 & 548.7 & 1.12 \\
\hline T105023 & & & 355.3 & 355.2 & 1.00 & 384.3 & 1.08 \\
\hline T105025 & & & 741.4 & 741.3 & 1.00 & 617.8 & 0.83 \\
\hline T106001 & & & 186.1 & 184.2 & 0.99 & 161.1 & 0.87 \\
\hline T106002 & & & 187.4 & 203.1 & 1.08 & 248.9 & 1.33 \\
\hline T106004 & & & 302.5 & 299.6 & 0.99 & 417.9 & 1.38 \\
\hline T106005 & & & 427.5 & 436.4 & 1.02 & 601.7 & 1.41 \\
\hline T106006 & & & 515.5 & 507.4 & 0.98 & 610.6 & 1.18 \\
\hline T106007 & & & 604.1 & 597.6 & 0.99 & 916.6 & 1.52 \\
\hline T108038 & & & 136.1 & 127.5 & 0.94 & 118.6 & 0.87 \\
\hline T108042 & & & 377.4 & 370.5 & 0.98 & 279.8 & 0.74 \\
\hline T107004 & \multirow{7}{*}{ 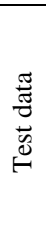 } & \multirow{7}{*}{$\begin{array}{c}\text { Not } \\
\text { available }\end{array}$} & 309.0 & 348.4 & 1.13 & 211.8 & 0.69 \\
\hline T105002 & & & 119.9 & 109.3 & 0.91 & 111.4 & 0.93 \\
\hline T105007 & & & 345.3 & 326.9 & 0.95 & 309.1 & 0.90 \\
\hline \begin{tabular}{|l|} 
T105018 \\
\end{tabular} & & & 255.7 & 242.4 & 0.95 & 276.0 & 1.08 \\
\hline T105024 & & & 362.9 & 371.1 & 1.02 & 376.2 & 1.04 \\
\hline T106003 & & & 266.1 & 230.6 & 0.87 & 297.9 & 1.12 \\
\hline T108032 & & & 218.5 & 249.3 & 1.14 & 234.3 & 1.07 \\
\hline
\end{tabular}


Table 8. Initial stiffness comparison for welded joints.

\begin{tabular}{|c|c|c|c|c|c|c|c|}
\hline Test & & Author & $\begin{array}{l}S_{j, \text { ini EXP }} \\
\text { (kN.m) }\end{array}$ & $\begin{array}{c}S_{j, \text { ini ANN }} \\
(\mathrm{kN} . \mathrm{m} / \mathrm{rad})\end{array}$ & $\begin{array}{c}S_{j, \text { ini ANN }} / \\
S_{j, \text { ini EXP }} \\
\end{array}$ & $\begin{array}{c}S_{j, \text { ini } E C 3} \\
(\mathrm{kN} . \mathrm{m} / \mathrm{rad})\end{array}$ & $\begin{array}{c}S_{j, \text { ini ECз }} \\
S_{j, \text { ini EXP }} \\
\end{array}$ \\
\hline \begin{tabular}{|l|} 
T107001 \\
\end{tabular} & \multirow{26}{*}{ 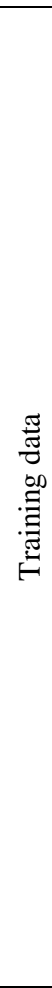 } & \multirow{26}{*}{$\begin{array}{c}\text { Not } \\
\text { available }\end{array}$} & 20123 & 30649 & 1.52 & 26844 & 1.33 \\
\hline \begin{tabular}{|l|} 
T107002 \\
\end{tabular} & & & 29090 & 13197 & 0.45 & 41773 & 1.44 \\
\hline T107003 & & & 44366 & 15503 & 0.35 & 63405 & 1.43 \\
\hline T105003 & & & 69707 & 45252 & 0.65 & 71618 & 1.03 \\
\hline T105004 & & & 94903 & 71426 & 0.75 & 122489 & 1.29 \\
\hline T105005 & & & 81278 & 48644 & 0.60 & 99294 & 1.22 \\
\hline \begin{tabular}{|l|} 
T105006 \\
\end{tabular} & & & 250565 & 155032 & 0.62 & 327779 & 1.31 \\
\hline T105008 & & & 83115 & 80520 & 0.97 & 97168 & 1.17 \\
\hline T105009 & & & 9555 & 17052 & 1.78 & 14985 & 1.57 \\
\hline T105011 & & & 16331 & 31522 & 1.93 & 25924 & 1.59 \\
\hline \begin{tabular}{|l|} 
T105014 \\
\end{tabular} & & & 46663 & 47279 & 1.01 & 41686 & 0.89 \\
\hline \begin{tabular}{|l|} 
T105015 \\
\end{tabular} & & & 38442 & 77620 & 2.02 & 56351 & 1.47 \\
\hline \begin{tabular}{|l|} 
T105016 \\
\end{tabular} & & & 46415 & 53074 & 1.14 & 52876 & 1.14 \\
\hline \begin{tabular}{|l|} 
T105019 \\
\end{tabular} & & & 113997 & 155418 & 1.36 & 146575 & 1.29 \\
\hline T105020 & & & 95555 & 109471 & 1.15 & 142192 & 1.49 \\
\hline \begin{tabular}{|l|} 
T105021 \\
\end{tabular} & & & 165577 & 149758 & 0.90 & 200717 & 1.21 \\
\hline \begin{tabular}{|l|} 
T105023 \\
\end{tabular} & & & 73928 & 91871 & 1.24 & 91818 & 1.24 \\
\hline \begin{tabular}{|l|} 
T105025 \\
\end{tabular} & & & 125306 & 160598 & 1.28 & 178057 & 1.42 \\
\hline \begin{tabular}{|l|} 
T106001 \\
\end{tabular} & & & 70526 & 72473 & 1.03 & 49086 & 0.70 \\
\hline T106002 & & & 120454 & 119081 & 0.99 & 94700 & 0.79 \\
\hline \begin{tabular}{|l|} 
T106004 \\
\end{tabular} & & & 103710 & 107656 & 1.04 & 151362 & 1.46 \\
\hline T106005 & & & 97945 & 139544 & 1.42 & 198496 & 2.03 \\
\hline \begin{tabular}{|l|} 
T106006 \\
\end{tabular} & & & 182755 & 166204 & 0.91 & 192871 & 1.06 \\
\hline T106007 & & & 207268 & 176463 & 0.85 & 341795 & 1.65 \\
\hline \begin{tabular}{|l|} 
T108038 \\
\end{tabular} & & & 30591 & 45472 & 1.49 & 31632 & 1.03 \\
\hline \begin{tabular}{|l|} 
T108042 \\
\end{tabular} & & & 72616 & 90133 & 1.24 & 90032 & 1.24 \\
\hline \begin{tabular}{|l|} 
T107004 \\
\end{tabular} & \multirow{7}{*}{ 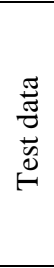 } & \multirow{7}{*}{$\begin{array}{c}\text { Not } \\
\text { available }\end{array}$} & 72594 & 49965 & 0.69 & 183629 & 2.53 \\
\hline \begin{tabular}{|l|} 
T105002 \\
\end{tabular} & & & 49837 & 56773 & 1.14 & 89934 & 1.80 \\
\hline \begin{tabular}{|l|} 
T105007 \\
\end{tabular} & & & 106281 & 67078 & 0.63 & 156396 & 1.47 \\
\hline T105018 & & & 73919 & 98026 & 1.33 & 85526 & 1.16 \\
\hline \begin{tabular}{|l|} 
T105024 \\
\end{tabular} & & & 93851 & 133223 & 1.42 & 118421 & 1.26 \\
\hline \begin{tabular}{|l|} 
T106003 \\
\end{tabular} & & & 64634 & 67974 & 1.05 & 107983 & 1.67 \\
\hline T108032 & & & 34948 & 43781 & 1.25 & 57033 & 1.63 \\
\hline
\end{tabular}

Table 9. Flexural resistance comparison for bolted joints with angles.

\begin{tabular}{|c|c|c|c|c|c|c|}
\hline Test & Author & $\begin{array}{c}M_{j, R d \text { EXP }} \\
\text { (kN.m) }\end{array}$ & $\begin{array}{c}M_{j, R d A N N} \\
\text { (kN.m) }\end{array}$ & $\begin{array}{c}\mathrm{M}_{\mathrm{j}, \mathrm{Rd} \text { ANN }} / \\
\mathrm{M}_{\mathrm{j}, \mathrm{Rd} \text { EXP }}\end{array}$ & $\begin{array}{c}M_{j R d E C 3} \\
\text { (kN.m) }\end{array}$ & $\begin{array}{c}M_{j R d \text { EC3 }} / \\
M_{j, R d \text { EXP }}\end{array}$ \\
\hline $8 S 1$ & \multirow{14}{*}{$\begin{array}{l}\text { Azizinamini et al. (1987) and } \\
\text { Azizinamini et al. (1989) }\end{array}$} & 37.2 & 43.7 & 1.17 & 29.2 & 0.78 \\
\hline $8 \mathrm{~S} 2$ & & 43.4 & 43.7 & 1.01 & 39.6 & 0.91 \\
\hline $8 \mathrm{S3}$ & & 47.7 & 40.1 & 0.84 & 36.4 & 0.76 \\
\hline $8 \mathrm{~S} 4$ & & 18.6 & 18.4 & 0.99 & 15.3 & 0.83 \\
\hline $8 \mathrm{S5}$ & & 38.1 & 37.5 & 0.98 & 33.6 & 0.88 \\
\hline $8 \mathrm{S6}$ & & 27.6 & 34.6 & 1.25 & 29.2 & 1.06 \\
\hline $8 S 7$ & & 43.0 & 37.5 & 0.87 & 27.1 & 0.63 \\
\hline $8 \mathrm{~S} 10$ & & 71.6 & 71.6 & 1.00 & 64.5 & 0.90 \\
\hline 14S1 & & 77.7 & 85.6 & 1.10 & 61.3 & 0.79 \\
\hline 14S2 & & 107.0 & 106.5 & 1.00 & 129.2 & 1.21 \\
\hline 14S4 & & 92.9 & 85.6 & 0.92 & 87.1 & 0.94 \\
\hline $14 \mathrm{~S} 5$ & & 86.2 & 84.8 & 0.98 & 64.5 & 0.75 \\
\hline 14S6 & & 119.0 & 121.4 & 1.02 & 103.8 & 0.87 \\
\hline 14S8 & & 176.4 & 174.5 & 0.99 & 150.6 & 0.85 \\
\hline $8 S 8$ & \multirow{4}{*}{$\begin{array}{l}\text { Azizinamini et al. (1987) and } \\
\text { Azizinamini et al. (1989) }\end{array}$} & 42.9 & 36.3 & 0.85 & 31.6 & 0.74 \\
\hline $8 S 9$ & & 47.8 & 42.3 & 0.89 & 42.2 & 0.88 \\
\hline $14 \mathrm{S3}$ & & 73.9 & 66.9 & 0.90 & 52.0 & 0.70 \\
\hline 14S9 & & 115.7 & 121.4 & 1.05 & 103.8 & 0.90 \\
\hline
\end{tabular}


Table 10. Initial stiffness comparison for bolted joints with angles.

\begin{tabular}{|c|c|c|c|c|c|c|}
\hline Test & Author & $\begin{array}{l}S_{j, \text { ini EXP }} \\
\text { (kN.m) }\end{array}$ & $\begin{array}{l}S_{j, \text { ini ANN }} \\
\text { (kN.m) }\end{array}$ & $\begin{array}{l}S_{j, \text { ini ANN }} / \\
S_{i, \text { ini EXP }}\end{array}$ & $\begin{array}{c}S_{j, \text { ini CHEN }} \\
\text { (kN.m) }\end{array}$ & $\begin{array}{c}S_{j, \text { ini CHEN }} / \\
S_{j, \text { ini EXP }}\end{array}$ \\
\hline $8 \mathrm{~S} 1$ & \multirow{14}{*}{$\begin{array}{l}\text { Azizinamini et al. (1987) and } \\
\text { Azizinamini et al. (1989) }\end{array}$} & 7540 & 12026.16 & 1.59 & 5611 & 0.74 \\
\hline $8 \mathrm{~S} 2$ & & 13940 & 12026.16 & 0.86 & 10368 & 0.74 \\
\hline $8 \mathrm{~S} 3$ & & 11830 & 8245.749 & 0.70 & 7481 & 0.63 \\
\hline $8 \mathrm{~S} 4$ & & 1730 & 746.042 & 0.43 & 385 & 0.22 \\
\hline $8 \mathrm{~S} 5$ & & 8670 & 7717.94 & 0.89 & 5082 & 0.59 \\
\hline $8 \mathrm{~S} 6$ & & 4460 & 5455.3 & 1.22 & 2084 & 0.47 \\
\hline $8 \mathrm{~S} 7$ & & 5420 & 7717.94 & 1.42 & 3812 & 0.70 \\
\hline $8 \mathrm{~S} 10$ & & 48200 & 47576.94 & 0.99 & 35564 & 0.74 \\
\hline 14S1 & & 22030 & 24203.53 & 1.10 & 14365 & 0.65 \\
\hline 14S2 & & 33330 & 31692.2 & 0.95 & 37491 & 1.12 \\
\hline 14S4 & & 25070 & 24203.53 & 0.97 & 14365 & 0.57 \\
\hline 14S5 & & 27900 & 27337.21 & 0.98 & 17128 & 0.61 \\
\hline 14S6 & & 32300 & 32826.89 & 1.02 & 44826 & 1.39 \\
\hline $14 \mathrm{~S} 8$ & & 65400 & 66235.6 & 1.01 & 79953 & 1.22 \\
\hline 8S8 & \multirow{4}{*}{$\begin{array}{l}\text { Azizinamini et al. (1987) and } \\
\text { Azizinamini et al. (1989) }\end{array}$} & 7900 & 9995.946 & 1.27 & 7154 & 0.91 \\
\hline 8S9 & & 11800 & 12944.25 & 1.10 & 13250 & 1.12 \\
\hline 14S3 & & 13090 & 15159.87 & 1.16 & 14365 & 1.10 \\
\hline 14S9 & & 29200 & 32826.81 & 1.12 & 44826 & 1.54 \\
\hline
\end{tabular}

\section{Conclusions}

This paper proposes the use of artificial neural networks to predict the flexural resistance and initial stiffness of beam-tocolumn joints. The neural network results for the prediction of the flexural resistance for all joints types conducted to satisfactory results. However, the results obtained for the initial stiffness showed the necessity to incorporate new experimental data. These results are summarized in Tab. 11.

The authors would like to emphasize that the initial stiffness experimental values are strongly influenced by the measurement system. Recent investigations (Neves et al., 2003), pointed out to the use of the elastic unload stiffness value instead of the initial stiffness values found in the first loading stages. The main reason for that procedure is related to the various accommodation displacements/slip found in these joints in early loading phases. The elastic stiffness found in the unloading phase does not present these accommodations, which provides a better representation of the joint initial stiffness. Since all the joints data do not use the above mentioned procedure, scattered results can be expected in the experimental initial stiffness joint values.

The mean errors obtained in this investigation were $8.4 \%, 8.9 \%$ and $11.6 \%$ for the prediction of the flexural resistance, demonstrating a reasonable agreement between the neural networks and the experimental test values. These errors are acceptable when compared to the level of safety factors used in structural engineering and the intrinsic errors associated with the used experimental data.

Table 11. Error summary.

\begin{tabular}{|c|c|c|c|c|c|}
\hline \multicolumn{2}{|c|}{ Joint Type } & MAPE training $(\%)$ & $\mathrm{MAPE}_{\text {test }}(\%)$ & $\begin{array}{l}\text { Minimum percentile } \\
\text { training error (\%) }\end{array}$ & $\begin{array}{l}\text { Maximum percentile } \\
\text { training error (\%) }\end{array}$ \\
\hline \multirow{2}{*}{ Endplate } & $M_{i, R d \text { ANN }}$ & 9.8 & 8.4 & -15.5 & 18.0 \\
\hline & $S_{j, \text { ini ANN }}$ & 5.9 & 23.5 & -33.8 & 38.3 \\
\hline \multirow{2}{*}{ Welded } & $M_{i, R d \text { ANN }}$ & 4.0 & 8.9 & -15.4 & 12.4 \\
\hline & $S_{j, \text { ini ANN }}$ & 35.6 & 28.0 & -58.4 & 30.0 \\
\hline \multirow{2}{*}{$\begin{array}{l}\text { Bolted with } \\
\text { angles }\end{array}$} & $M_{i, R d \text { ANN }}$ & 6.8 & 11.6 & -18.3 & 4.7 \\
\hline & $S_{j, \text { ini ANN }}$ & 22.3 & 13.6 & -131.9 & 37.3 \\
\hline
\end{tabular}

It is also fair to mention that the small number of experimental data can be one of the factors associated to the relative large Neural Networks errors. The incorporation of new data, acquired in laboratory tests, will surely improve the quality of the Neural Networks predictions.

The present investigation confirmed the possibility of using this technique to generate trustworthy data. The use of artificial neural networks coupled with experimental data will enable the execution of a parametric analyses. These numerical analyses will surely help the calibration of the design code formulations like the Eurocode 3.

\section{Acknowledgements}

Financial support from "CAPES - Coordenação de Aperfeiçoamento de Pessoal de Nível Superior - Brazil” and “CNPq
- Conselho Nacional de Desenvolvimento Científico e Tecnológico” are gratefully acknowledged.

\section{References}

Abdala, K. M. and Stavroulakis, G. E., A., 1995, "Backpropagation Neural Network Model for Semi-Rigid Joints", Microcomputers in Engineering, vol. 10, pp. 77-87.

Aggarwal, A. K., 1994, "Comparative Tests on end Plate Beam-toColumn Joints”, Journal of Constructional Steel Research, Vol. 30, pp. 151175.

Anderson, D. et al., 1997, "Application of Artificial Neural Networks to the Prediction of Minor Axis Joints", Computers \& Structures, Vol. 63, pp. 685-692.

Azizinamini, A., Bradburn, J. H. and Radziminski, J., 1987, "Initial Stiffness of Semi-Rigid Steel Beam-to-Column Joints", Journal of Constructional Steel Research, Vol. 8, pp. 71-90. 
Azizinamini, A. and Radziminski, J., 1989, "Static and Cyclic Performance of Semi-Rigid Steel Beam-to-Column Joints”, Journal of Structural Engineering, ASCE, Vol. 115, N 12.

Bjorhovde, R., Colson, A. and Brozzetti. J., 1990, "Classification System for Beam-To-Column Joints”. Journal of Structural Division, ASCE, Vol. 116, ST11, pp. 3059-3076.

Chen, W. F., Lorens, R.F. and Kato, B., 1993, "Semi-Rigid Joints in Steel Frames”. McGraw-Hill, Inc.

Cruz, P. J. S., Silva, L. A. P. S. da, Rodrigues, D. S. and Simões, R. A. D., 1998, "Database for the Semi-Rigid Behaviour of Beam-to-column Joints in Seismic Regions", Journal of Constructional Steel Research, Vol. 46, pp. 1-12.

Cybenko. 1989, “Approximation by Superpositions of a Sigmoidal Function”, Mathematics of Control, Signals and Systems”, Vol. 2, pp. 303314.

CEN, Eurocode 3, EN1993-1-8: Design of Joints, May 2003, CEN, European Committee for Standardization, Brussels, p. 124.

Faella, C., Piluso, V. and Rizzano. G., 1999, "Structural Steel SemiRigid Joints - Theory, Design and Software”, CRC Press, p. 505.

Goverdan, A. V., A, 1993, "Collection of Experimental momentRotation Curves and Evaluation of Prediction Equations for Semi-Rigid Joints”, Vanderbilt University, Nashville, Tennessee.

Haykin, S., 1999, "Neural Networks - A Comprehensive Foundation”, Macmillan College Publishing Company, Inc.

Hornik, K., Stinchcombe, M. and White, H., 1989, "Multilayer Feedforward Networks are Universal Approximators”. Neural Networks, Vol. 2, pp. 359-366.

Hummer, C. and Tschemmernegg, T., “A Non-Linear Joint Model for the Design of Structural Steel Frames”. Costruzioni Metalliche, No. 1.

Bishop, C. M., 1994, "Neural Networks and Their Applications". Review Scientific Instruments, American Institute of Physics, Vol. 65, Issue 6, pp. 1803-1832.

Janss, J., Jaspart, J. P. and Maquoi. R., 1997, "Experimental Study of Non-linear Behaviour of Beam-to-column Bolted Joints", Joints in Steel Structures: Behaviour, Strength and Design - Proceedings of the $1^{\text {st }}$ International Workshop on Joints, France.

Jaspart, J. P., 1997, "Recent Advances in the Field of Steel Joints Column Bases and Further Configurations for Beam-to-Column Joints and Beam Splices”, Chercheur qualifié du F.N.R.S., Universite de Liege, Faculte des Sciences Appliques.

Kishi, N., Chen, W. F. and Matsuoka, K. G., 1987, "Moment-Rotation Relation of Top-and-Seat Angle with Double Web-Angle Joints”, Joints in
Steel Structures, Bjorhovde, Brazzeti and Colson Editors, Elsevier, pp. 121134.

Lima, L. R. O. de, Vellasco, P. C. G. da S., and Andrade. S. A. L. de, Silva, L. A. P. S. da, 2002, "Experimental and Mechanical Model for Predicting the Behaviour of Minor Axis Beam-to-Column Semi-Rigid Joints”, International Journal of Mechanical Sciences, Australia, Vol. 44, N ${ }^{\circ}$. 6, pp. 1047-1065.

Mitchel, T. M.,1997, “Machine Learning”, McGraw-Hill.

Nethercot, D. A., Li, T. Q. and Choo, B. S., 1995, "Determination of Rotation Capacity Requirements for Steel and Composite Beams”, Journal of Constructional Steel. Research, Vol. 32, pp. 303-332.

Neves, L. F. da C., Silva, L. A. P. S. da and Vellasco, P. G. C. da S. 2003, "Experimental Behaviour of End Plate I-beam to Concrete-filled Rectangular Hollow Section Column Joints Under Cyclic Loading”, Proceedings of the Fourth International Conference on Behaviour of Steel Structures in Seismic Areas, Naples, Italy, pp. 277-283.

“Qnet for Windows - Neural Network Modelling”, 2000, V2K build 721. User Manual, Vesta Services, Inc., Copyright (c)

Rumelhart, D. E. and McClelland, J. L., 1986, "Parallel Distributed Processing: Explorations in the Microstructure of Cognition”, MIT Press, Cambridge.

Silva, L. S. da and Coelho, A. M. G., A., 2001, "Ductility Model for Steel Joints”, Journal of Constructional Steel Research, Vol. 57, pp. 45-70.

Simek and Wald, F., 1991, "Test Results on Endplate Beam-to-Column Joints”. CTU, G-1121 Report. Prague.

Simões, R. Simões da Silva, L. and Cruz, P., 2001, "Behaviour of EndPlate Beam-to-Column Composite Joints Under Cyclic Loading”, International Journal of Steel and Composite Structures, Vol. 1, N ${ }^{\circ} 3$, pp. 355-376.

Stavroulakis, G. E. and Abdala, K. M., 1994, “A systematic Neural Network Classificator in Mechanics”, Application in Semi-Rigid Steel Joints, International Journal of Engineering Analysis and Design, Vol. 1 pp. 279-292.

Treleaven P., Pacheco, M. A. C. and Vellasco, M. M. B. R., 1989 "VLSI Architectures for Neural Networks", IEEE Micro Vol. 9, No 6, pp. 827.

Weynand, K. and Sahl. R., 1984, "The Structure for Databases of Test Results of Semi-Rigid Joints”, COST-C1 Second State of the Art Workshop, Prague, pp. 405-418.

Zoetemeijer, P. and Munter. H., 1983, "Extended Endplate with Disappointing Rotation Capacity: Test Results and Analysis”, Report 6-7520 KV-4, University of Technology, Delft. 